\title{
Respon Pertumbuhan dan Hasil Tanaman Jagung Manis terhadap Pemberian Dosis Limbah Industri Pengolahan Karet pada Tanah Podsolik
}

\section{(Growth and Yield Response Sweet Corn to Giving Dosage of Rubber Processing Industrial Waste on Podsolic Soils)}

\author{
Khairullah $^{1)}$, Mahdiannoor ${ }^{2)} \&$ Norhasanah $^{3)}$ \\ Program Studi Agroteknologi, Sekolah Tinggi Ilmu Pertanian Amuntai \\ ${ }^{1)}$ khair@gmail.com \\ ${ }^{2)}$ mahdi_186@yahoo.com \\ ${ }^{3)}$ hasanah_sandi@yahoo.com
}

\begin{abstract}
ABSTRAK
Jagung sebagai bahan pangan menempati urutan kedua setelah padi, selain itu juga digunakan sebagai bahan pakan ternak dan bahan baku industri. Rendahnya produktivitas jagung karena kesuburan tanah yang bervariasi dan tidak menggunakan varietas unggul. Untuk meningkatkan hasil produksi yang tinggi perlu adanya pemupukan,baik pupuk kimia maupun pupuk organik seperti pada tanah podsolik. Tujuan penelitian ini (i) mengetahui respon pertumbuhan dan hasil tanaman jagung terhadap pemberian limbah industri pengolahan karet pada tanah podsolik (ii) mendapatkan dosis terbaik limbah industri pengolahan karet bagi pertumbuhan dan hasil tanaman jagung pada tanah podsolik. Penelitian dilaksanakan di Desa Haruyan Seberang RT 05 RW 02 Kec. Haruyan Kab, Hulu Sungai Tengah, dari bulan April - Juni 2012, menggunakan Rancangan Acak Kelompok (RAK) dengan 5 perlakuan dan 5 ulangan, sehingga terdapat 25 satuan percobaan. Faktor yang diuji adalah pemberian beberapa dosis limbah

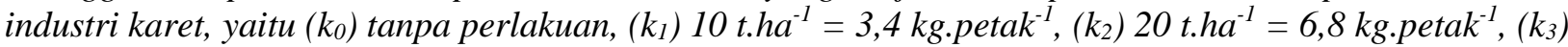
30 t.ha $a^{-1}=10,2$ kg.petak ${ }^{-1}$ dan ( $\left.k_{4}\right) 40$ t.ha $a^{-1}=13,6$ kg.petak $^{-1}$. Hasil penelitian menunjukan respon diameter batang jagung umur 21 dan 28 HST, jumlah daun umur 14 HST dan panjang tongkol jagung pertanaman; tidak ada respon tinggi tanaman umur 14, 21 dan 28 HST, diameter batang umur 14 HST, jumlah daun umur 21 dan 28 HST dan berat tongkol pertanaman terhadap perlakuan pemberian dosis limbah industri karet. Dosis terbaik limbah industri pengolahan karet untuk pertumbuhan dan hasil tanaman jagung adalah 40 t.ha $a^{-1}\left(13,6\right.$ kg.petak $\left.{ }^{-1}\right)$.
\end{abstract}

Kata kunci : Jagung, industri, limbah, karet, podsolik.

\section{ABSTRACT}

Corn as a food ingredient ranks second after rice, besides it is also used as animal feed ingredients and industrial raw materials. Low productivity of corn due to varied soil fertility and not using superior varieties. To increase high yields, fertilization is needed, both chemical fertilizers and organic fertilizers such as podsolic soil. The purpose of this study $(i)$ to determine the response of growth and yield of maize to the provision of rubber processing industry waste on podsolic soil (ii) get the best dose of rubber processing industry waste for the growth and yield of corn plants on podsolic soil. The study was conducted in the village of Haruyan Seberang RT 05 Rw 02 Kec. Haruyan Kab, Hulu Sungai Tengah, from April June 2012, used a Randomized Block Design (RBD) with 5 treatments and 5 replications, so that there were 25 experimental units. The factors tested were the administration of several doses of rubber industry waste, namely $\left(k_{0}\right)$ without treatment, $\left.\left(k_{1}\right) 10 \mathrm{t} \cdot \mathrm{ha}^{-1}=3.4 \mathrm{~kg}_{\mathrm{plot}}{ }^{-1},\left(k_{2}\right) 20 \mathrm{t} \cdot \mathrm{ha^{-1 }}=6.8 \mathrm{~kg} \cdot \mathrm{plot}^{-1}, \mathrm{k}_{3}\right) 30 \mathrm{t} \cdot \mathrm{ha}$ ${ }^{1}=10.2 \mathrm{~kg} \mathrm{plot}^{-1}$ and $\left(\mathrm{k}_{4}\right) 40 \mathrm{t} \cdot \mathrm{ha}^{-1}=13.6 \mathrm{~kg} \cdot \mathrm{plot}^{-1}$. The results showed the response of corn stalk diameter aged 21 and 28 DAP, number of leaves aged 14 DAP and length of corn cobs planted; there was no response of plant height aged 14, 21 and 28 DAP, stem diameter of 14 DAP, number of leaves aged 21 and 28 DAP and weight of ear of crop on treatment of dosing of rubber industry waste. The best dose of rubber processing industry waste for growth and yield of corn plants is 40 t.ha $a^{-1}\left(13.6 \mathrm{~kg}^{\mathrm{p}} \mathrm{plot}^{-1}\right)$.

Keywords: Corn, industry, waste, rubber, podzolic. 


\section{PENDAHULUAN}

Jagung merupakan tanaman hasil pertanian di Indonesia jagung sebagai makanan pokok kedua setelah padi, sedangkan urutan bahan makanan pokok di dunia jagung menduduki urutan ketiga setelah gandum dan padi. Jagung selain bahan pangan juga digunakan sebagai bahan baku industri pakan ternak. Produksi sampingan berupa batang, daun, dan kelobot dapat di manfaatkan sebagai bahan pakan ternak atau untuk pupuk kompos (Purwono dan Hartono, 2005).

Berdasarkan data Badan Pusat Statistik (BPS) Kalimantan Selatan. Produksi jagung pada tahun 2007 meningkat mencapai 100.957 ton, sedangkan pada tahun 2008 produksi jagung menurun menjadi 95.064 ton mengalami sedikit penurunan dari produksi tahun 2007, turunnya sebesar 5.893 ton atau $5,84 \%$. Penurunan produksi jagung ini disebabkan karena adanya penurunan luas panen yang cukup besar yaitu 2.125 ha. Meskipun hasil per hektar meningkat 1,84 kwintal/ha. Penurunan luas panen ini disebabkan oleh panen muda yang dilakukan oleh petani jagung. Kemudian pada tahun 2009 produksi jagung mengalami peningkatan menjadi 97.326 ton. Hasil produksi ini meningkat yaitu sebesar 2.262 ton dibandingkan pada tahun 2008. Pada tahun 2010 produksi jagung di Kalimantan Selatan mengalami peningkatan mencapai 4.651 ton atau $4,08 \%$, sehingga menjadi 118,536 ton. Peningkatan tersebut disebabkan oleh adanya kenaikan luas panen seluas 533 ha. Sedangkan pada tahun 2011 produksi jagung mengalami sedikit penurunan kembali menjadi 100.056 ton, penurunan ini disebabkan turunnya luas panen sebanyak 3.033 ha atau $13,43 \%$ dibandingkan pada tahun 2010 (Barito Post, 2011).

Rendahnya produktivitas jagung di Kalimantan Selatan disamping tingkat kesuburan tanahnya. Selain itu juga disebabkan masih kurangnya petani menggunakan varietas unggul. Salah satu usaha meningkatkan produktivitas jagung dapat dilakukan dengan menanam varietasvarietas hibrida (Untung, 1992).

Hulu Sungai Tengah memiliki lahan yang cukup luas 121.824 ha terdiri dari lahan sawah 53.407 ha, dan lahan kering 68.417 ha. Baru 2.564 ha yang telah dimanfaatkan untuk budidaya pertanian khususnya tanaman jagung hibrida maupun jagung lokal (Dinas Pertanian Tanaman Pangan dan Hortikultura Kab. HST, 2009).

Kendala dalam pengembangan pertanian ditanah podsolik ini ada memiliki permasalahan yakni kebanyakan lahannya miring sehingga mudah terjadi erosi, kandungan unsur hara dan bahan organiknya rendah. Dalam upaya peningkatan produksi jagung ditanah podsolik, kendala yang dihadapi adalah pemberian pupuk yang belum berimbang sering terlambat dalam waktu yang dianjurkan, penyiangan dan pembumbunan juga sering terlambat dan pengaturan jarak tanam yang belum diterapkan untuk tanaman jagung di tanah podsolik perlu ditambahkan pemupukan (Adisarwanto, 1999).

Limbah industri pengolahan karet termasuk limbah organik yang sesuai untuk dikelola sacara mikrobiologi. Karena limbah industri pengolahan karet ini mengandung unsur hara yang dibutuhkan oleh tanaman yaitu $\mathrm{N}, \mathrm{P}, \mathrm{K}$ dan memiliki $\mathrm{pH}$ netral. Pengaruh penambahan bahan organik terhadap $\mathrm{pH}$ tanah dapat meningkatkan atau menurunkan tergantung oleh tingkat kematangan bahan organik yang kita tambahkan dan jenis tanahnya. Penambahan bahan organik yang belum masak (misal pupuk hijau) atau bahan organik yang masih mengalami proses dekomposisi, biasanya akan menyebabkan penurunan $\mathrm{pH}$ tanah, karena selama proses dekomposisi akan melepaskan asam-asam organik yang menyebabkan menurunnya $\mathrm{pH}$ tanah. Namun apabila diberikan pada tanah yang masam dengan kandungan Al tertukar tinggi, akan menyebabkan peningkatan $\mathrm{pH}$ tanah, karena asam-asam organik hasil dekomposisi akan mengikat Al membentuk senyawa komplek (khelat), sehingga Al-tidak terhidrolisis lagi.

Dilaporkan bahwa penambahan bahan organik pada tanah masam, antara lain 
inseptisol, ultisol dan andisol mampu meningkatkan $\mathrm{pH}$ tanah dan mampu menurunkan Al tertukar tanah (Suntoro, 2001; Cahyani., 1996; dan Dewi, 1996). Peningkatan $\mathrm{pH}$ tanah juga akan terjadi apabila bahan organik yang kita tambahkan telah terdekomposisi lanjut (matang), karena bahan organik yang telah termineralisasi akan melepaskan mineralnya, berupa kationkation basa.

Menurut hasil analisis Laboratorium Kimia, Fisika dan Biologi Tanah (2011). Tanah Podsolik di Desa Haruyan Seberang Kecamatan Haruyan Kabupaten Hulu Sungai Tengah mengandung unsur nitrogen yang sangat rendah dengan nilai 0,09\%, C-Organik rendah dengan kandungan $1,42 \%, \mathrm{pH}$ tanah memiliki nilai 5,42 tergolong masam, $\mathrm{K}_{2} \mathrm{O}$ rendah dengan kandungan 17,50 mg/100g, $\mathrm{P}_{2} \mathrm{O}_{5}$ sangat rendah yaitu $1,12 \mathrm{ppm}$. Menurut hasil analisis Laboratorium Kimia, Fisika dan Biologi Tanah (2011). Limbah industri pengolahan karet mempunyai beberapa kriteria dan kandungan hara diantaranya COrganik dengan kandungan hara $15,06 \%$ yaitu sangat tinggi sedangkan unsur $\mathrm{N}$ dengan nilai $0,60 \%$ kriteria tinggi, $\mathrm{P}$ dengan kandungan hara $1,01 \%$ dengan kriteria sangat rendah, $\mathrm{K}$ dengan nilai 0,03\% dengan kriteria sangat rendah dan $\mathrm{pH}$ tanah netral dengan kandungan 7,54.

Penggunaan limbah padat industri kertas sebanyak $70 \%$ dapat meningkatkan pertambahan tinggi batang tanaman sengon setelah umur tanam 4 minggu (Soetopo et. al., 2010). Aplikasi tandan kosong sawit (TKS) dengan dosis 40 dan 60 ton TKS/ha/tahun sebagai mulsa tanpa aplikasi pupuk standar dapat meningkatkan produksi secara berturut-turut $11 \%$ dan $13 \%$ diatas produksi kontrol (dilakukan pemupukan standar tetapi tanpa aplikasi TKS), sedangkan aplikasi 40 ton TKS /ha yang dikombinasikan dengan $60 \%$ dosis pupuk urea dan RP dari standar kebun dapat meningkatkan produksi TBS sebesar 34\% dari perlakuan standar (Sutarta et. al., 2012).

Tujuan penelitian ini adalah (i) mengetahui respon pertumbuhan dan hasil tanaman jagung terhadap pemberian limbah industri pengolahan karet pada tanah podsolik dan (ii) mendapatkan dosis terbaik limbah industri pengolahan karet bagi pertumbuhan dan hasil tanaman jagung pada tanah podsolik.

\section{METODE PENELITIAN}

Penelitian ini dilaksanakan di Desa Haruyan Seberang Kecamatan Haruyan Kabupaten Hulu Sungai Tengah yang dilaksanakan pada bulan April - Juni 2012. Bahan dan alat yang digunakan adalah benih jagung, lahan, limbah industri pengolahan karet, air dan pestisida. Alat-alat yang digunakan adalah alat pengolah tanah. meteran. digunakan untuk mengukur tinggi dan jarak tanam, tugal, gembor, handsprayer, timbangan, penggaris, alat tulis, alat dokumentasi dan jangka sorong.

Penelitian ini merupakan percobaan yang dilakukan di lapangan dengan rancangan perlakuan Rancangan Acak Kelompok (RAK) faktor tunggal dengan pengelompokkan berdasarkan distribusi cahaya matahari pada lapangan percobaan. Faktor yang diteliti adalah pemberian dosis limbah industri pengolahan karet (k) sebanyak 5 taraf yaitu : $\mathrm{k}_{0}: 0$ ton.ha ${ }^{-1}$ setara dengan $0 \mathrm{~kg} /$ petak, $\mathrm{k}_{1}: 10$ ton.ha ${ }^{-1}$ setara dengan 3,4 kg / petak, $\mathrm{k}_{2}: 20$ ton.ha ${ }^{-1}$ setara dengan $6,8 \mathrm{~kg} /$ petak, $\mathrm{k}_{3}: 30$ ton.ha ${ }^{-1}$ setara dengan 10,2 kg/ petak, $\mathrm{k}_{4}: 40$ ton.ha ${ }^{-1}$ setara dengan 13,6 kg / petak. Masing-masing percobaan diulang sebanyak 5 kali ulangan, sehingga terdapat 25 tanaman perpetak satuan percobaan dan setiap satuan percobaan terdiri dari 12 tanaman.

Pelaksanaan penelitian meliputi persiapan, pelaksanaan pengolahan tanah, penanaman, pemeliharaan dan pemanenan. pengamatan yang dilakukan adalah tinggi tanaman, diameter batang tanaman, jumlah daun, berat tongkol pertanaman dan panjang tongkol.

Setelah data terkumpul, maka terlebih dahulu dilakukan uji kehomogenan ragam. Apabila data homogen untuk mengetahui ada tidaknya pengaruh perlakuan pemberian dosis limbah industri pengolahan karet terhadap pertumbuhan dan hasil tanaman jagung, maka dilakukan uji - F pada taraf 
nyata $5 \%$ dan $1 \%$. Apabila uji $-\mathrm{F}$ menunjukkan pengaruh nyata atau sangat nyata, pengujian dilanjutkan dengan Uji Beda rata-rata pada taraf nyata $5 \%$.

HASIL DAN PEMBAHASAN

Hasil
Hasil analisis ragam menunjukan bahwa tidak ada respon tinggi tanaman jagung manis umur 14, 21 dan 28 HST terhadap perlakuan pemberian dosis limbah industri pengolahan karet. Rata-rata tinggi tanaman jagung manis terhadap pemberian dosis limbah pengolahan industri karet pada umur 14, 21 dan 28 HST dapat dilihat pada Gambar 1.

\section{Tinggi Tanaman}

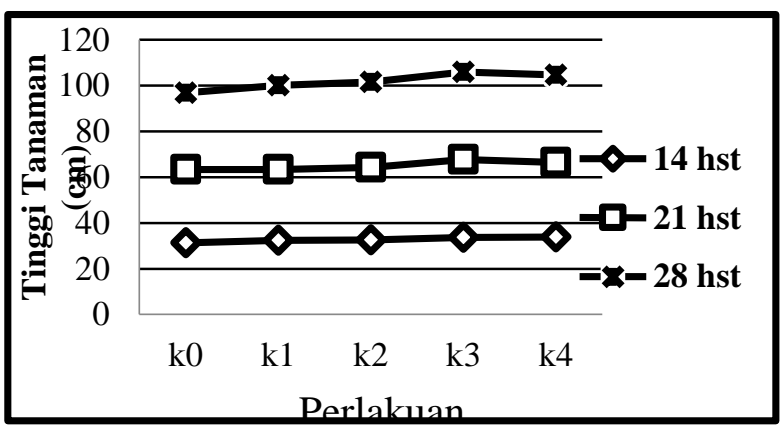

Gambar 1. Grafik rata-rata tinggi tanaman jagung manis 14, 21 dan 28 HST terhadap pemberian dosis limbah pengolahan industri karet.

Dari Gambar 1 terlihat bahwa pada umur 14 HST, tinggi tanaman jagung tertinggi terdapat pada perlakuan $\mathrm{k}_{4}$ yaitu $33,9 \mathrm{~cm}$, pada umur $21 \mathrm{HST}$ tinggi tanaman

\section{Diameter Batang}

Hasil analisis ragam menunjukan bahwa tidak ada respon diameter batang tanaman jagung umur 14 HST terhadap perlakuan pemberian dosis limbah industri jagung tertinggi terdapat pada perlakuan $\mathrm{k}_{3}$ yaitu $67,71 \mathrm{~cm}$, sedangkan pada umur 28 HST perlakuan tertinggi terdapat pada $\mathrm{k}_{3}$ yaitu $105,96 \mathrm{~cm}$

pengolahan karet, tetapi memberikan respon terhadap diameter batang tanaman jagung manis umur 21 dan 28 HST. Hasil uji beda rata-rata diameter batang tanaman jagung dapat dilihat pada Tabel 1.

Tabel 1. Uji beda rata-rata diameter batang tanaman jagung manis umur 14, 21 dan 28 HST terhadap pemberian dosis limbah industri pengolahan karet.

\begin{tabular}{cccc}
\hline \multirow{2}{*}{ Perlakuan } & \multicolumn{3}{c}{ Rata-rata diameter batang tanaman jagung $(\mathrm{cm})$} \\
\cline { 2 - 4 } & $14 \mathrm{HST}$ & $21 \mathrm{HST}$ & $28 \mathrm{HST}$ \\
\hline $\mathrm{k}_{0}$ & 0,396 & $1,354_{\mathrm{a}}$ & $2,158_{\mathrm{a}}$ \\
$\mathrm{k}_{1}$ & 0,392 & $1,204_{\mathrm{ab}}$ & $1,996_{\mathrm{ab}}$ \\
$\mathrm{k}_{2}$ & 0,388 & $1,34_{\mathrm{ab}}$ & $2,042_{\mathrm{ab}}$ \\
$\mathrm{k}_{3}$ & 0,4 & $1,414_{\mathrm{ab}}$ & $2,38_{\mathrm{bc}}$ \\
$\mathrm{k}_{4}$ & 0,462 & $1,534_{\mathrm{b}}$ & $2,514_{\mathrm{c}}$ \\
\hline
\end{tabular}

Keterangan : Nilai rata-rata yang diikuti huruf yang sama pada kolom yang sama menunjukan perlakuan tersebut tidak berbeda berdasarkan BNT pada $\operatorname{taraf} 5 \%$

Dari Tabel 2 terlihat bahwa pada umur 14 HST, rata-rata diameter batang tanaman jagung tidak berbeda dengan umur
21 dan 28 HST. Pada umur 21 HST terjadi perbedaan antara $\mathrm{k}_{1}$ dan $\mathrm{k}_{4}$ perlakuan terbaik terdapat pada $\mathrm{k}_{1}$. Pada umur $28 \mathrm{HST}$ terjadi 
perbedaan antara $\mathrm{k}_{3}$ dan $\mathrm{k}_{4}$, perlakuan terbaik terdapat pada $\mathrm{k}_{3}$.

\section{Jumlah Daun}

Dari hasil analisis ragam terdapat respon jumlah daun tanaman jagung manis umur 14 HST, tetapi tidak ada respon jumlah daun umur 21 dan 28 HST terhadap perlakuan pemberian dosis limbah industri pengolahan karet. Hasil uji beda rata-rata jumlah daun umur 14,21 dan 28 HST disajikan pada Tabel 2.

Tabel 2. Hasil uji beda rata-rata jumlah daun tanaman jagung manis akibat pemberian dosis limbah industri pengolahan karet pada umur 14, 21 dan 28 HST.

\begin{tabular}{cccc}
\hline \multirow{2}{*}{ Perlakuan } & \multicolumn{3}{c}{ Rata-rata jumlah daun tanaman jagung (helai) } \\
\cline { 2 - 4 } & $14 \mathrm{HST}$ & $21 \mathrm{HST}$ & $28 \mathrm{HST}$ \\
\hline $\mathrm{k}_{0}$ & $3,5_{\mathrm{a}}$ & 6,6 & 9 \\
$\mathrm{k}_{1}$ & $3,8_{\mathrm{ab}}$ & 6,5 & 9,2 \\
$\mathrm{k}_{2}$ & $3,7_{\mathrm{b}}$ & 6,6 & 9 \\
$\mathrm{k}_{3}$ & $3,9_{\mathrm{b}}$ & 6,8 & 9,2 \\
$\mathrm{k}_{4}$ & $3,9_{\mathrm{b}}$ & 6,9 & 9,8 \\
\hline
\end{tabular}

Keterangan : Nilai rata-rata yang diikuti huruf yang sama pada kolom yang sama menunjukan perlakuan tersebut tidak berbeda nyata bedasarkan BNT pada taraf $5 \%$

Dari Tabel 2 terlihat bahwa pada umur 14 HST jumlah daun tanaman jagung

\section{Berat Tongkol Pertanaman}

Hasil analisis ragam menunjukan bahwa tidak terdapat respon berat tongkol pertanaman jagung manis terhadap perlakuan terbaik terdapat pada perlakuan $\mathrm{k}_{1}$ yang tidak berbeda dengan perlakuan $\mathrm{k}_{1}, \mathrm{k}_{2}, \mathrm{k}_{3}$ dan $\mathrm{k}_{4}$.

pemberian dosis limbah industri pengolahan karet. Rata-rata berat tongkol tanaman jagung manis disajikan pada Gambar 2.

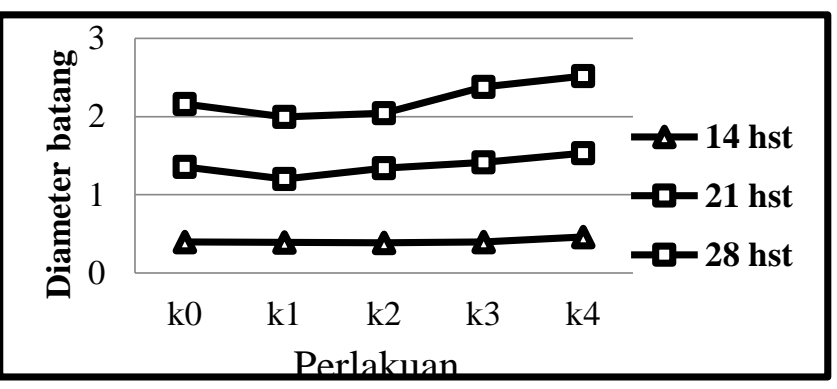

Gambar 2. Grafik rata-rata diameter batang tanaman jagung manis terhadap pemberian limbah industri pengolahan karet umur 14, 21 dan 28 HST.

Dari Gambar 2 terlihat bahwa berat tongkol tanaman jagung tertinggi terdapat pada perlakuan $\mathrm{k}_{3}$ yaitu $435 \mathrm{~g}$.

\section{Panjang Tongkol Pertanaman}

Berdasarkan analisis ragam terdapat respon panjang tongkol pertanaman jagung manis terhadap perlakuan pemberian dosis limbah industri pengolahan karet. Hasil uji beda rata-rata panjang tongkol tanaman jagung dapat dilihat pada Tabel 3.

Tabel 3. Hasil uji beda rata-rata panjang tongkol tanaman jagung manis terhadap pemberian dosis limbah industri pengolahan karet 


\begin{tabular}{cc}
\hline Perlakuan & Rata-rata panjang tongkol jagung $(\mathrm{cm})$ \\
\hline $\mathrm{k}_{0}$ & $27,3_{\mathrm{a}}$ \\
$\mathrm{k}_{1}$ & $27_{\mathrm{a}}$ \\
$\mathrm{k}_{2}$ & $27,2_{\mathrm{a}}$ \\
$\mathrm{k}_{3}$ & $28,5_{\mathrm{ab}}$ \\
$\mathrm{k}_{4}$ & $28,85_{\mathrm{b}}$ \\
\hline
\end{tabular}

Keterangan : Nilai rata-rata yang diikuti huruf yang sama pada kolom yang sama menunjukan perlakuan tersebut tidak berbeda berdasarkan BNT pada taraf 5\%

Dari Tabel 3 terlihat bahwa rata-rata panjang tongkol tanaman jagung manis terbaik terdapat pada perlakuan $\mathrm{k}_{3}$ yaitu 28,5 $\mathrm{cm}$ yang tidak berbeda dengan perlakuan $\mathrm{k}_{1}$, $\mathrm{k}_{2}, \mathrm{k}_{3}$ dan $\mathrm{k}_{4}$.

\section{Pembahasan}

\section{Tinggi Tanaman}

Dari hasil analisis ragam menunjukan bahwa tidak terdapat respon tinggi tanaman jagung manis umur 14, 21 dan 28 HST terhadap pemberian perlakuan dosis limbah industri pengolahan karet. Hal ini disebabkan ketersediaan unsur hara didalam tanah maupun limbah industri pengolahan ktidak mencukupi dalam proses pertumbuhan dan perkembangan vegetatif tanaman.

Dari hasil analisis tanah menggambarkan pentingnya $\mathrm{pH}$ tanah untuk mengatur ketersediaan unsur hara bagi tanaman jagung, yaitu untuk memudahkan tidaknya unsur-unsur hara yang diserap tanaman. Pada umumnya unsur hara yang mudah diserap akar tanaman, pada $\mathrm{pH}$ tanah sekitar netral kebanyakan unsur hara mudah larut dalam air. Pada pH masam 5,42 unsur $\mathrm{N}, \mathrm{P}$ dan $\mathrm{K}$ tidak dapat diserap oleh tanaman karena difiksasi oleh $\mathrm{Al}$, sehingga tinggi tanaman jagung umur 14, 21 dan 28 HST tidak memberikan respon.

Menurut Hardjowigeno (2003), mengemukakan kecukupan unsur hara berupa $\mathrm{N}$ untuk pertumbuhan vegetatif tanaman jagung batasan unsur hara yang diserap oleh tanaman yaitu $\mathrm{N}$ total $(3,0 \%)$, sedangkan di Lampiran 3 disajikan hasil analisis tanah memiliki kandungan unsur hara sangat rendah $\mathrm{N}$ total yaitu $(0,09 \%)$. Kemudian $\mathrm{N}$ total dianalisis limbah industri pengolahan karet tinggi yaitu $\mathrm{N}$ total $(0,60 \%)$, hal ini juga di pengaruhi $\mathrm{pH}$ tanah dan proses dekomposisi bahan organik yang lambat dalam menyediakan unsur-unsur yang diperlukan tanaman.

Menurut Wijaya (2008), ketersediaan unsur $\mathrm{N}$ yang terkandung didalam bahan organik tanah dipengaruhi oleh proses dekomposisi bahan organik yang lambat dalam menyediakan unsur-unsur hara yang diperlukan oleh tanaman khususnya unsur nitrogen yang sangat berperan dalam menunjang pertumbuhan vegetatif tanaman.

Tim Penulis (1993), menyatakan bahwa tanaman yang berumur satu sampai dua minggu setelah tanam. Biasanya berada dalam tahap penyesuaian terhadap lingkungan baru, hal ini disebabkan pada fase inilah pertumbuhan vegetatif tanaman memerlukan unsur hara makro nitrogen dalam jumlah yang cukup.

Dilihat dari hasil analisis tanah maupun limbah karet ketersedian unsur $\mathrm{N}$ di limbah memang tinggi, sedangkan unsur $\mathrm{N}$ di analisis tanah memiliki nilai $\mathrm{N}$ sangat rendah. Jadi ketersedian $\mathrm{N}$ bagi pertumbuhan tanaman memerlukan waktu yang relatif lambat untuk dijadikan sumber makanan bagi tanaman jagung,mengakibatkan tinggi tanaman jagung tidak memperlihatkan respon nyata pada tanaman itu sendiri.

\section{Diameter Batang Tanaman}

Berdasarkan hasil analisis ragam tidak terdapat respon diameter batang tanaman jagung manis terhadap perlakuan pemberian dosis limbah industri pengolahan karet umur 14 HST tetapi terdapat respon diameter batang tanaman jagung manis umur 21 dan 28 HST.

Berdasarkan hasil analisis tanah yang digunakan ialah tanah podsolik mempunyai produktivitas rendah hingga sedang, dengan kandungan unsur hara dan bahan organik 
rendah, $\mathrm{pH}$ tanah berkisar 5,42 tergolong masam dan kapasitas tukar kation dan kejenuhan basa rendah serta daya ikat dan aerasi tanah yang kurang baik sehingga peka terhadap erosi (Sitorus, 1979). Dalam kondisi inilah penyerapan unsur hara makro dan mikro terlambat khususnya unsur nitrogen lambat tersedia bagi tanaman, sehingga umur 14 HST diameter tanaman jagung tidak memperlihatkan respon. Dari hasil analisis tanah dan hasil analisis limbah karet ketersediaan unsur P khususnya di limbah karet tidak mencukupi bagi pertumbuhan akar atau batang tanaman jagung, sedangkan unsur $\mathrm{P}$ di tanah ini tinggi dikarenakan proses dekomposisi yang lambat tersedia bagi tanaman jagung mengakibatkan umur 14 HST diameter batang tidak memberikan hasil. Sedangkan pada umur 21 dan 28 HST diakibatkan lambatnya proses dekomposisi pada limbah karet menyediakan unsur hara baik itu N, P dan K. Fungsi N diantaranya untuk pembentukan atau pertumbuhan bagian vegetatif tanaman, seperti daun, batang dan akar. Sedangkan Fungsi $P$ diantaranya merangsang pertumbuhan akar, khususnya akar benih/tanaman muda. Mempercepat serta memperkuat pertumbuhan tanaman muda menjadi tanaman dewasa dan menaikkan prosentase bunga menjadi buah/biji. Membantu asimilasi dan pernafasan sekaligus mempercepat pembungaan dan pemasakan buah, biji atau gabah.

Tanaman yang kekurangan unsur $\mathrm{N}$ gejalanya : pertumbuhan lambat/kerdil, daun hijau kekuningan, daun sempit, pendek dan tegak, daun-daun tua cepat menguning dan mati. Tanaman yang kekurangan unsur $P$ gejaalanya : pembentukan buah/dan biji berkurang, kerdil, daun berwarna keunguan atau kemerahan (kurang sehat). Tanaman yang kekurangan unsur K gejalanya : batang dan daun menjadi lemas/rebah, daun berwarna hijau gelap kebiruan tidak hijau segar dan sehat, ujung daun menguning dan kering, timbul bercak coklat pada pucuk daun.

\section{Jumlah Daun}

Dari hasil analisis ragam menunjukan bahwa terdapat respon jumlah daun tanaman jagung manis umur 14 HST tetapi tidak terdapat respon jumlah daun tanaman jagung manis umur 21 dan 28 HST. Hal ini disebabkan karena batasan kecukupan unsur hara $\mathrm{N}$ yang tersedia diserap tanaman terhadap proses berlangsungnya pertumbuhan tanaman menurut (Hardjowigeno, 2003), unsur nitrogen mampu memberikan hasil terbaik pada jumlah daun dengan kadar $\mathrm{N}$ total $(3,0 \%)$, sedangkan unsur $\mathrm{N}$ dalam analisis limbah industri pengolahan karet dan analisis tanah hanya $0,60 \%$ dan $0,09 \%$ hal ini yang menyebabkan pada umur 21 dan 28 HST tidak memberikan adanya respon pada jumlah daun. Fungsi unsur $\mathrm{N}$ yaitu diperlukan untuk pembentukan atau pertumbuhan bagian vegetatif tanaman, seperti daun, batang dan akar. Berperan penting dalam hal pembentukan hijau daun yang berguna sekali dalam proses fotosintesis. Membentuk protein, lemak dan berbagai persenyawaan organik. Meningkatkan mutu tanaman penghasil daun- daunan meningkatkan perkembangbiakan mikro-organisme di dalam tanah.

\section{Berat Tongkol Pertanaman}

Berdasarkan hasil analisis ragam tidak terdapat respon berat tongkol pertanaman jagung manis terhadap perlakuan pemberian dosis limbah industri pengolahan karet. Hal ini disebabkan unsur hara yang diserap tanaman jagung tidak mencukupi untuk memproses berat tongkol buah yang sempurna, kekurangan serapan unsur hara $\mathrm{P}$ dan K mengakibatkan berat tongkol tanaman jagung tidak ada respon nyata. Menurut (Hardjowigeno, 2003) batas kecukupan hara P $0,25 \%$ dan K 1,90. Sedangkan Hasil analisis limbah industri pengolahan karet unsur $\mathrm{P}$ hanya 1,01 dan $\mathrm{K} 0,03$ sehingga tidak terdapat respon berat tongkol pertanaman jagung manis.

Ketersediaan unsur $\mathrm{P}$ dan $\mathrm{K}$ akibat pemberian limbah industri pengolahan karet baik itu berupa bahan organik tergantung pada proses dekomposisi, proses dekomposisi ini sangat dipengaruhi sekali oleh $\mathrm{pH}$ tanah. Apabila $\mathrm{pH}$ tanah tergolong masam maka penyerapan unsur $\mathrm{P}$ dan $\mathrm{K}$ menjadi terlambat tersedia bagi tanaman 
jagung untuk mengahasilkan berat buah yang maksimal sehingga dalam penelitian ini memperlihatkan tidak adanya respon yang nyata pada berat tongkol tanaman jagung. Fungsi $\mathrm{P}$ yaitu merangsang pertumbuhan akar, khususnya akar benih/tanaman muda. Mempercepat serta memperkuat pertumbuhan tanaman muda menjadi tanaman dewasa dan menaikkan prosentase bunga menjadi buah/biji. Membantu asimilasi dan pernafasan sekaligus mempercepat pembungaan dan pemasakan buah, biji atau gabah.

Sebagai bahan mentah untuk pembentukan sejumlah protein tertentu. Gejala kekurangan $\mathrm{P}$ dan $\mathrm{K}$ yaitu pada tanaman yang kekurangan unsur $\mathrm{P}$ gejaalanya : pembentukan buah/dan biji berkurang, kerdil, daun berwarna keunguan atau kemerahan (kurang sehat). Tanaman yang kekurangan unsur $\mathrm{K}$ gejalanya : batang dan daun menjadi lemas/rebah, daun berwarna hijau gelap kebiruan tidak hijau segar dan sehat, ujung daun menguning dan kering, timbul bercak coklat pada pucuk daun.

\section{Panjang Tongkol Pertanaman}

Berdasarkan analisis ragam terdapat respon panjang tongkol pertanaman jagung manis terhadap perlakuan pemberian dosis limbah industri pengolahan karet. Proses pembentukan panjang buah tanaman jagung khususnya unsur $\mathrm{P}$ dan $\mathrm{K}$ karena kedua unsur ini sangat erat hubungannya untuk menghasilkan panjang buah, fungsi kedua unsur ini diantaranya unsur $P$ yaitu mempercepat serta memperkuat pertumbuhan tanaman muda menjadi tanaman dewasa dan menaikkan prosentase bunga menjadi buah/biji, sedangkan unsur $\mathrm{K}$ yaitu berperan memperkuat tubuh tanaman, mengeraskan jerami dan bagian kayu tanaman, agar daun, bunga dan buah tidak mudah gugur.

Dari dua unsur diatas baru kita melihat bahwa ketersedian unsur $\mathrm{P}$ ditanah mencukupi bagi tanaman jagung untuk menghasilkan panjang tongkol walaupun di analisis limbah karet sangat rendah. Tersedianya unsur P ditanah mengakibatkan panjang tongkol tanaman jagung berespon sebaliknya nusur $\mathrm{K}$ yang tersedia bagi tanaman jagung untuk menghasilkan panjang tongkol yang normal. Tanaman yang kekurangan unsur $\mathrm{P}$ gejaalanya : pembentukan buah/dan biji berkurang, kerdil, daun berwarna keunguan atau kemerahan (kurang sehat). Tanaman yang kekurangan unsur K gejalanya : batang dan daun menjadi lemas/rebah, daun berwarna hijau gelap kebiruan tidak hijau segar dan sehat, ujung daun menguning dan kering, timbul bercak coklat pada pucuk daun.

\section{KESIMPULAN}

Perlakuan limbah industri pengolahan karet memberikan respon terhadap diameter batang tanaman jagung 21 dan 28 HST, jumlah daun 14 dan panjang tongkol jagung. Akan tetapi tidak memberikan respon terhadap tinggi tanaman 14, 21 dan 28 HST, diameter batang umur 14 HST, jumlah daun umur 21 dan 28 HST dan berat tongkol tanaman jagung. Hasil perlakuan terbaik pada pertumbuhan dan hasil tanaman jagung manis terdapat pada dosis 10 t. ha $^{-1}(3,4$ kg. petak $\left.^{-1}\right)$.

\section{DAFTAR PUSTAKA}

Adisarwanto, T. dan Widayastuti, Y.E. 1999. Meningkatkan Produksi Jagung. Penebar Swadaya. Jakarta.

Barito Post. 2010. Produksi Palawija. Kalsel. 2010 Meningkat. Barito Post edisi Jum'at 16 Juli 2010. Banjarmasin.

Dinas Pertanian Pangan dan Hortikultura. 2009. Laporan Dinas Pertanian Pangan dan Hortikultura. Kabupaten Hulu Sungai Tengah.

Hardjowigeno, S. 2003. Ilmu Tanah. Penerbit Akademika Pressindo. Jakarta.

Laboratorium Fisika, Kimia dan Biologi Tanah. 2011. Hasil Analisis Tanah. Faperta Unlam. Banjarbaru. 
Purwono dan Hartono. R. 2005. Bertanam Jagung Unggul (Zea mays L.) Seri Agribisnis. Penerbit Penebar Swadaya. Jakarta.

Sitorus, B.M.A. 1979. Potensi tanah podsolik Untuk Pertanian Tadah Hujan. Fakultas Pertanian. Universitas Lambung Mangkurat. Banjarbaru.

Soetopo. R. S. Krisna Septiningrum, Aep Surahman. 2010. Potensi kompos dari limbah padat pabrik juss paper untuk meningkatkan produktivitas tanaman. Berita Selulosa. Vol. 45. No. 1 Juni 2010

Suntoro, 2001. Pengaruh residu penggunaan bahan organik, dolomit dan kcl pada tanaman kacang tanah (Arachis hypogeae L.) pada Oxic Dystrudeptdi Jumapolo, Karanganyar.

Sutarta, E. S. Darmosarkoro W dan Rahutomo S. 2012. Peluang penggunaan pupuk majemuk dan pupuk organik dari limbah kelapa sawit.

Tim Penulis. 1993. Sweet Corn Baby Corn. Penebar Swadaya. Jakarta.

Untung, R 1992. Sampai Tahun 2000 Prospek Jagung Masih Baik. Trubus Nomor 247. Th XXII

Wijaya, K. A. 2008. Nutrisi Tanaman Penentu Kualitas Hasil dan Resestensi Alami Tanaman. Prestasi Pustaka Pulisher. Jakarta. 